\title{
PARASITIC INFECTIONS OF TWO INVASIVE FISH SPECIES, THE CAUCASIAN DWARF GOBY AND THE AMUR SLEEPER, IN HUNGARY
}

\author{
László ANTAL ${ }^{1}$, Csaba SzÉKELY ${ }^{2}$ and Kálmán MOLNÁR ${ }^{2 *}$ \\ ${ }^{1}$ Department of Hydrobiology, University of Debrecen, Debrecen, Hungary; \\ ${ }^{2}$ Institute for Veterinary Medical Research, Centre for Agricultural Research, \\ Hungarian Academy of Sciences, P.O. Box 18, H-1581 Budapest, Hungary
}

(Received 24 July 2015; accepted 28 October 2015)

\begin{abstract}
In recent years and decades, two new fish species, the Caucasian dwarf goby (Knipowitschia caucasica) and the Amur sleeper (Perccottus glenii) have become members of the Hungarian fish fauna. In a 14-month study on the parasite fauna of these species, the authors detected 11 parasite species in the Caucasian dwarf goby and 17 species in the Amur sleeper. All parasites found in dwarf goby belong to species commonly occurring also in native Hungarian fishes, but three species (Goussia obstinata, Gyrodactylus perccotti and Nippotaenia mogurndae) collected from the Amur sleeper are introduced species new for the Hungarian fauna.
\end{abstract}

Key words: Parasite, native, non-indigenous, invasive fish species, PontoCaspian, Perccottus glenii, Knipowitschia caucasica

In recent years and decades the Hungarian fish fauna has been expanded by several new invasive fish species. Of them, the appearance of a series of Ponto-Caspian gobies and the Amur sleeper Perccottus glenii in the territory of the Danube and Tisza Rivers (Bíró, 1972; Erös and Guti, 1997; Harka, 1998; Guti, 2000; Guti et al., 2003; Harka et al., 2005; Harka and Bíró, 2007; Takács et al., 2011) deserves special mention. The latter species was documented in the Balaton catchment area, where it had presumably arrived via fish transport from the Tisza catchment area (Erős et al., 2008; Reshetnikov, 2010). More recently, a new sand goby species, the Caucasian dwarf goby (Knipowitschia caucasica) has been found in the Tisza River basin (Halasi-Kovács et al., 2011; Harka et al., 2013, 2015a, 2015b).

The climate change will modify the ecological impacts of invasive species by enhancing their competitive effects on native species, and then the introduction of such species into ecosystems may contribute to the loss of biodiversity (Thomas et al., 2004; Rahel and Olden, 2008; Bellard et al., 2012). These invasive species also introduced a part of their parasite fauna to the new biotope, and

*Corresponding author; E-mail: molnar@vmri.hu; Phone: 0036 (1) 467-4064 
since parasites can play an important role in determining the final outcome of competition between invasive and native species, monitoring the parasite fauna of invasive fish species is a very important task (Torchin et al., 2003; Prenter et al., 2004; Sokolov and Zhukov, 2014).

Data on the parasite fauna of these gobies in Central Europe have been presented by Molnár (2000, 2006), Francová et al. (2011) and Ondračková et al. (2012). Endoparasitic helminths of the Amur sleeper in the Carpathian basin were studied by Košuthová et al. (2004, 2008, 2009). Further data on the parasite infections of this fish species have been presented in the works of Mierzejewska et al. $(2010,2012)$ from Poland and of Kvach et al. $(2013,2014)$ and Zaichenko (2015) from the Ukraine. The enrichment of the parasite fauna of the Amur sleeper during its spread to the European part of Russia was thoroughly studied by Sokolov and Frolov (2012) and Sokolov (2013) in the original biotope of the fish in the Far East, and in the European part of Russia (Sokolov et al., 2012a, 2013). From the European stock of the Amur sleeper Sokolov and Moshu (2014) described a new species, Goussia obstinata, from the intestine. Little is known about the parasitic infection of small-sized sand gobies. Data have been reported only on their Gyrodactylus fauna. Of the latter, Osmanov (1971) described G. bubyri from the Caucasian dwarf goby, and Vanhove et al. (2014) described further Gyrodactylus spp. from Knipowitschia and Economidichthys spp.

This paper reports the results of a survey conducted for recording parasitic infections of two invasive fish species that have conquered water bodies in Hungary in recent years, the Caucasian dwarf goby and the Amur sleeper.

\section{Materials and methods}

Caucasian dwarf gobies were collected with hand nets from the Lake Tisza close to the city of Tiszafüred, while Amur sleepers were collected by electrofishing (Hans Grassl IG200/2B, Hans Grassl GmbH, Germany) from April 2014 to June 2015 (except in winter) from oxbows of the Tisza River and the channels close to it (Table 1). Altogether 66 dwarf goby and 169 Amur sleeper specimens were dissected from the main study area in the Tisza basin, and further six Amur sleeper specimens were derived from the tributary of the Zala River close to Lake Balaton (Table 1). Fish were collected in different periods of the year, starting in April and ending in November. As far as possible, different age groups were selected. From the dwarf goby, fingerlings measuring $1.5-1.7 \mathrm{~cm}$ in total length and one-year-old mature specimens achieving 3.5 to $3.7 \mathrm{~cm}$ in length were studied. The size of the Amur sleepers varied between 3 and $16 \mathrm{~cm}$. The fish were placed into plastic bags filled with oxygen and sent to the laboratory for detailed parasitological dissection. The dissections were performed within three days of collection. Fish were anaesthetised with a drop of claw oil into their wa- 
ter and their heads were cut afterwards. Dissections were made under a Zeiss stereomicroscope. All organs were checked for infection with parasites. Photos on parasites were taken using Nomarski differential interference contrast with an Olympus $\mathrm{BH} 2$ microscope and photographed with an Olympus DP 20 digital camera.

\section{Table 1}

List of sampling locations of Caucasian dwarf goby (Knipowitschia caucasica) and Amur sleeper (Perccottus glenii)

\begin{tabular}{|c|c|c|c|}
\hline Water body & Location & Code & Co-ordinates \\
\hline \multicolumn{4}{|l|}{ Perccottus glenii } \\
\hline Belfö-csatorna & Tiszabercel & $\mathrm{b}$ & $48^{\circ} 09^{\prime} 48.4^{\prime \prime} \mathrm{N} 21^{\circ} 40^{\prime} 04.1^{\prime \prime} \mathrm{E}$ \\
\hline Cserőközi-Holt-Tisza & Tiszaderzs & $\mathrm{c}$ & $47^{\circ} 31^{\prime} 18.5^{\prime \prime} \mathrm{N} 20^{\circ} 39^{\prime} 50.0^{\prime \prime} \mathrm{E}$ \\
\hline Keleti-föcsatorna & Balmazújváros & $\mathrm{k}$ & $47^{\circ} 37^{\prime} 43.9^{\prime \prime} \mathrm{N} 21^{\circ} 22^{\prime} 18.3^{\prime \prime E}$ \\
\hline Lónyai-föcsatorna & Gávavencsellő & 1 & $48^{\circ} 08^{\prime} 38.4^{\prime \prime} \mathrm{N} 21^{\circ} 37^{\prime} 47.0^{\prime \prime} \mathrm{E}$ \\
\hline Rakamazi-Nagy-morotva & Tiszanagyfalu & $\mathrm{r}$ & $48^{\circ} 05^{\prime} 42.7^{\prime \prime} \mathrm{N} 21^{\circ} 27^{\prime} 45.8^{\prime \prime} \mathrm{E}$ \\
\hline Tiszacsegei-Nagy-morotva & Tiszacsege & $\mathrm{t}$ & $47^{\circ} 40^{\prime} 07.6^{\prime \prime} \mathrm{N} 20^{\circ} 56^{\prime} 08.1^{\prime \prime} \mathrm{E}$ \\
\hline Zala River & Fenékpuszta & $\mathrm{z}$ & $46^{\circ} 42^{\prime} 04.2^{\prime \prime} \mathrm{N} 17^{\circ} 15^{\prime} 26.0^{\prime \prime} \mathrm{E}$ \\
\hline \multicolumn{4}{|l|}{ Knipowitschia caucasica } \\
\hline Lake Tisza & Tiszafüred & lt & $47^{\circ} 37^{\prime} 34.1^{\prime \prime} \mathrm{N} \mathrm{20} 44^{\prime} 10.0^{\prime \prime} \mathrm{E}$ \\
\hline
\end{tabular}

\section{Results}

A total of 11 parasite species were found in the Caucasian dwarf goby (Table 2). The most common infection was caused by an Apiosoma sp., a commensal organism, which, however, may become pathogenic after colonising the body surface of fish. Hundreds of these sessile ciliates covered mostly the fins of fish (Fig. 1A), but they were frequently found also in the gills. Apiosoma infection was frequently accompanied by the presence of the flagellate Cryptobia branchialis and some common ciliates such as Trichodina mutabilis, Hemiophrys branchiarum, and Chilodonella cyprini. In a single case a trophont of Ichthyophthirius multifiliis was also recorded. Of the metazoan parasites, metacestodes of a Proteocephalus species were the most common in the intestine of this fish species. Scolices of metacestodes in the dwarf goby had four wellobservable suckers and an inconspicuous fifth central sucker. Although these scolices had relatively long unsegmented strobilae, we were unable to identify them with an already described species (Fig. 1B). In the abdominal cavity, digenean metacercariae surrounded by a very thick wall and having a characteristic lemon shape (Fig. 1C) were frequently recorded. By their shape and thick wall resistant to compression these metacercariae were identified as Apatemon gracilis. Although less frequently, non-encysted specimens were also found (Fig. 1D), but their inner structure could not be studied in detail. Of the other 
helminths commonly infecting Hungarian fishes, Nicolla skrjabini and Camallanus truncatus in the gut and metacercariae of an Echinochasmus sp. in the gill filaments were accidentally found. In fishes examined in the spring and summer period, glochidia larvae of an Anodonta species were frequently recorded. All parasites found can be regarded as members of the Hungarian parasite fauna, and most of them had been found earlier also in the River Tisza (Ergens et al., 1975).

Table 2

List of parasites found in 66 Caucasian dwarf goby (Knipowitschia caucasica) specimens caught in the Lake Tisza, Hungary

\begin{tabular}{lcc}
\hline \multicolumn{1}{c}{ Name of parasite } & Site of infection in fish & Number of infected fish \\
\hline Cryptobia branchialis Nie (in Chen, 1956) & gill, fin & 19 \\
Apiosoma sp. & fin & 54 \\
Trichodina mutabilis Kazubski \& Migala, 1968 & gill, fin & 13 \\
Hemiophrys branchiarum (Weinrich, 1924) & gill, fin & 5 \\
Chilodonella cyprini Moroff, 1902 & gill & 3 \\
Ichthyophthirius multifiliis Fouquet, 1876 & gill & 1 \\
Proteocephalus sp. (1) & intestine & 23 \\
Nicolla skrjabini (Iwanitzky, 1928) & intestine & 2 \\
Echinochasmus sp. (1) & gill & 1 \\
Apatemon gracilis (Rudolphi, 1819) & abdominal cavity & 11 \\
Camallanus truncatus (Rudolphi, 1814) & gill, fin & 14
\end{tabular}

$1=$ larval stage

A total of 17 parasite species were found in the Amur sleeper (Table 3). Of them, three species (Goussia obstinata, Gyrodactylus perccotti and Nippotaenia mogurndae) belong to the original parasite fauna of this fish known also in its Far Eastern biotope (Fig. 2). Of the species common in other European fishes, the most frequently found species was Trichodina mutabilis, causing infection both in the fins and in the gills (Fig. 2A). Less frequently, in younger fish specimens, Trichodinella epizootica caused mixed infection with T. mutabilis. Of the other protozoans, compared to the members of the local fish fauna, relatively few species were recorded. Of them, the flagellate Spironucleus elegans was found to cause intensive infection in the intestine of some fish specimens. On the other hand, Goussia obstinata, a recently described species was frequently isolated from the gut of both young and old Amur sleeper specimens (Fig. 2B). Gyrodactylus perccotti was mostly found in the fins, but some of its specimens could be collected from the gills as well (Fig. 2C). Nippotaenia mogurndae infected only some of the stocks, but in these cases infection involving up to ten specimens could be found, located in different parts of the intestine. The species could be easily recognised by its large single oral sucker (Fig. 2D). Of the other cestodes, scolices of Proteocephalus percae were found in the rectum of one fish specimen. Nicolla skrjabini, a common trematode species with a wide host range was 


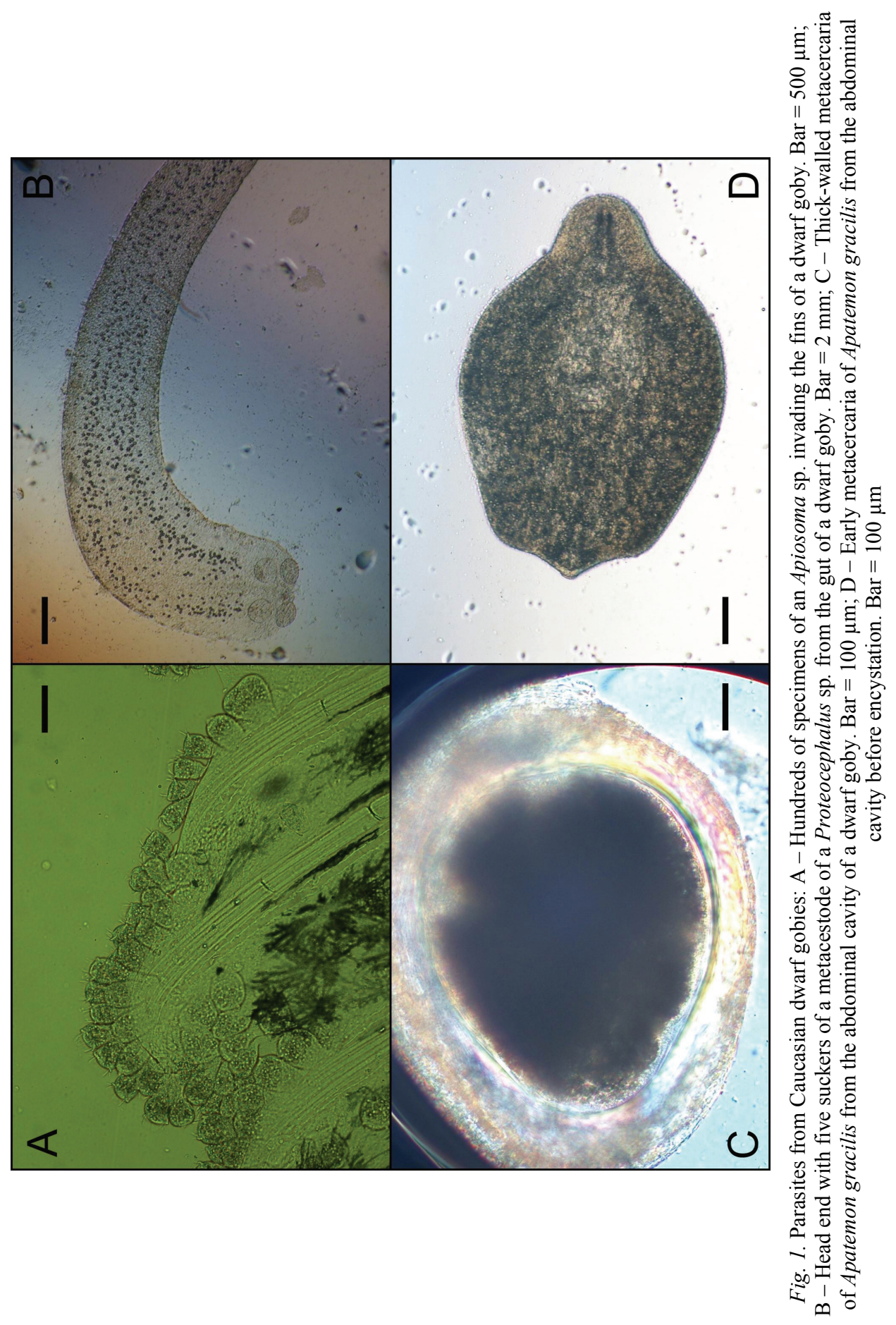


only recorded in two cases in Amur sleepers. Of the larval trematodes, the metacercariae of Opisthioglyphe ranae (Fig. 2E) infecting gill filaments were the most common. Other trematode larvae, among them the relatively large metacercariae of Clinostomum complanatum (Fig. 2F), occurred only incidentally. Like in the dwarf goby, glochidia of an Anodonta species were frequently recorded and caused well-observable infection in the fins and gills of the Amur sleeper as well (Fig. 2G).

Although heavy infections with the above parasites were often found, no fatal cases manifesting themselves in disease signs were recorded.

Table 3

List of parasites found in 169 Amur sleeper (Perccottus glenii) specimens from the region of the Tisza and Zala Rivers, Hungary

\begin{tabular}{|c|c|c|c|}
\hline Name of parasite & $\begin{array}{c}\text { Site of } \\
\text { infection } \\
\text { in fish }\end{array}$ & $\begin{array}{l}\text { Number of } \\
\text { infected } \\
\text { fish }\end{array}$ & $\begin{array}{l}\text { Location of } \\
\text { infection }^{+}\end{array}$ \\
\hline Spironucleus elegans Lavier, 1936 & intestine & 8 & $\mathrm{~b}, \mathrm{c}, \mathrm{l}, \mathrm{r}, \mathrm{h}$ \\
\hline Apiosoma sp. & fin & 1 & $\mathrm{r}$ \\
\hline Trichodina mutabilis Kazubsky \& Migala, 1968 & gill, fin & 70 & $\mathrm{~b}, \mathrm{c}, \mathrm{k}, \mathrm{r}, \mathrm{t}, \mathrm{z}$ \\
\hline Trichodinella epizootica Raabe, 1960 & fin & 4 & $1, \mathrm{r}$ \\
\hline${ }^{*}$ Goussia obstinata Sokolov \& Moshu, 2014 & intestine & 31 & $\mathrm{~b}, \mathrm{l}, \mathrm{r}, \mathrm{z}$ \\
\hline${ }^{*}$ Gyrodactylus perccotti Ergens \& Yukhimenko, 1973 & fin & 32 & $\mathrm{~b}, \mathrm{c}, \mathrm{k}, \mathrm{l}, \mathrm{r}, \mathrm{t}, \mathrm{z}$ \\
\hline${ }^{*}$ Nippotaenia mogurndae Yamaguti \& Miyata, 1940 & intestine & 18 & $\mathrm{~b}, \mathrm{r}$ \\
\hline Proteocephalus percae (Müller, 1780) (1) & intestine & 1 & $\mathrm{r}, \mathrm{z}$ \\
\hline Nicolla skrjabini (Iwanitzky, 1928) & intestine & 2 & $\mathrm{r}$ \\
\hline Echinochasmus sp. (1) & gill & 9 & $1, r, z$ \\
\hline Petasiger sp. (1) & gill & 1 & $\mathrm{r}$ \\
\hline Diplostomum spathaceum (Rudolphi, 1819) (1) & eye lens & 2 & b \\
\hline Opishyoglyphe ranae (Fröhlich, 1791) (1) & gill & 14 & $\mathrm{~b}, \mathrm{c}, \mathrm{l}, \mathrm{r}$ \\
\hline Clinostomum complanatum (Rudolphi, 1819) (1) & gill & 1 & $\mathrm{r}$ \\
\hline Spiroxis contortus (Rudophi, 1819) (1) & intestine & 4 & $\mathrm{k}, \mathrm{z}$ \\
\hline Ergasilus sieboldi Nordmann, 1832 & gill & 1 & $\mathrm{r}$ \\
\hline Anodonta sp. (glochidium) & gill, fin & 20 & $1, \mathrm{r}, \mathrm{t}$ \\
\hline
\end{tabular}

${ }^{+}$See Table 1 for the explanation of location codes; ${ }^{*}$ introduced species; 1 = larval stage

\section{Discussion}

Having evaluated the parasitic infections of the two goby species in Hungary, we may conclude that they have introduced relatively few new parasites to Hungary, compared to the original Far Eastern parasite fauna of the Amur sleeper (Sokolov and Frolov, 2012; Sokolov, 2013) or to data from the European part of Russia, Moldova, the Ukraine, and Poland (Sokolov and Moshu, 2013; Kvach et al., 2014; Sokolov et al., 2014). The relatively low number of parasitic species in the 


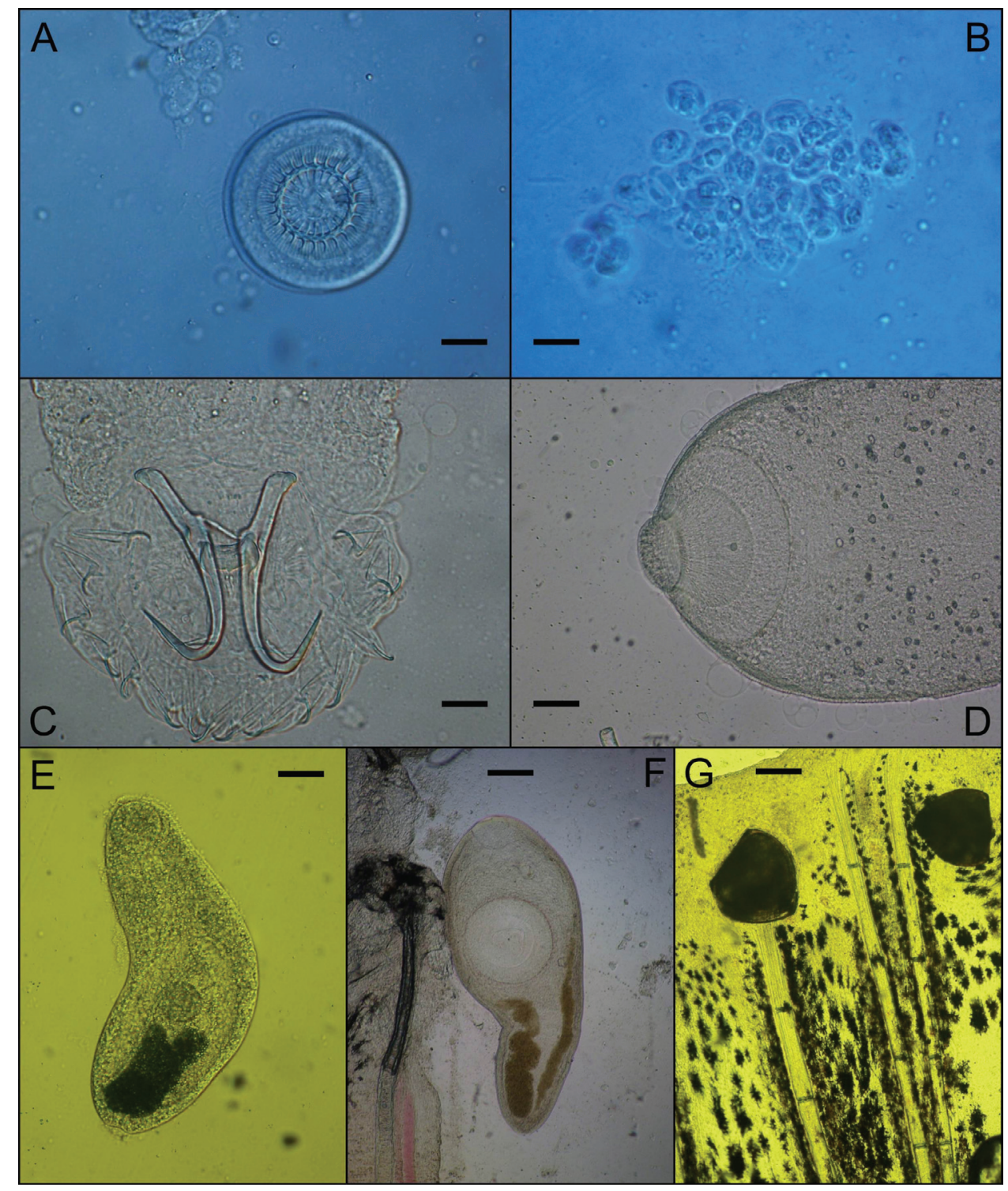

Fig. 2. Parasites from Amur sleeper: A - Trichodina mutabilis from the fins of a Amur sleeper. $\mathrm{Bar}=30 \mu \mathrm{m} ; \mathrm{B}-$ Sporocysts of Goussia obstinata from the gut of an Amur sleeper. Bar $=20 \mu \mathrm{m}$; $\mathrm{C}-$ Gyrodactylus perccotti from the fins of an Amur sleeper. Bar $=20 \mu \mathrm{m}$; D - Head end of Nippotaenia mogurndae with its single sucker. Bar $=400 \mu \mathrm{m} ; \mathrm{E}-$ Excysted metacercaria of

Opisthioglyphe ranae from the gills of an Amur sleeper. Bar $=1 \mathrm{~mm} ; \mathrm{F}-$ Excysted metacercaria of Clinostomum complanatum from the gill arch of an Amur sleeper. Bar $=2 \mathrm{~mm} ; \mathrm{G}-$ Glochidia of an Anodonta species attached to the fins of an Amur sleeper. Bar $=0.4 \mathrm{~mm}$ 
short-lived Caucasian dwarf goby is less surprising as this fish is a typical brackish-water species less common in freshwaters and its less studied parasite fauna seems to be of marine origin (Miller, 2004). Parasites found by us in this work are common parasites infecting Middle European freshwater fishes. Of the parasites found in these small fishes, an Apiosoma sp. deserves a mention, which infected the fins and gills of practically all of the fish examined, but other common flagellate and ciliate protozoans known from native fishes were also found (Molnár, 1979). Of the metazoan parasites, the common occurrence of a closely not identified metacercaria in the abdominal cavity presented a new record, because no similar thick-walled metacercariae had been recorded from Hungarian fishes up to this time. Despite the new record of this species, this parasite, which infects aquatic birds in its adult stage, cannot be regarded as an introduced parasite species. Larval stages of Proteocephalus spp. were found in the gut of both the dwarf goby and the Amur sleeper. They were, however, different in some respects. Proteocephalus larvae in the gut of the dwarf goby were in the metacestode stage, having a scolex and an unsegmented strobila and located in different parts of the gut lumen, while larvae in the gut of the Amur sleeper had only scolices and were located in the rectum. Scolices of the species infecting the dwarf goby had a conspicuous small fifth (central) sucker, while the central sucker of scolices found in the rectum of the Amur sleeper was well observable. Although we suppose that the species bearing scolices with the primordia of proglottids corresponds to $P$. torulosus, until obtaining conclusive molecular evidence we designate it as Proteocephalus sp. On the other hand, scolices found accumulated in the rectum of Amur sleeper showed great similarity to scolices commonly occurring in the rectum of the carrier host ruffe (Molnár, 1966), and they were identified as larval stages of $P$. percae.

Contrary to that of the dwarf goby, the parasite fauna of the Hungarian Amur sleeper population contains, besides the common Hungarian fish parasites, three introduced species (Nippotaenia mogurndae, Gyrodactylus perccotti and Goussia obstinata) known from the original Far Eastern biotope of this fish. Sokolov and Frolov (2012) as well as Sokolov (2013), who studied the parasite fauna of the Amur sleeper in its original biotope in the Far East by taking into consideration also data previously reported by other researchers, found 83 parasite species in the Amur sleeper. In another paper providing a checklist of the parasite fauna of the non-native Amur sleeper population based on the data of European and Russian authors, Sokolov et al. (2014) counted 67 identified parasite species and 30 species identified only to the genus or family level. Although the specific parasite fauna of the Amur sleeper in its native population is rich in specific parasites, aside from worldwide-distributed fish parasites, only three common species (Nippotaenia mogurndae, Gyrodactylus perccotti and Goussia obstinata) and a less common one (Henneguya alexeevi Shulman, 1962) have arrived with it in Europe and become parasites of the non-native populations 
(Košuthová et al., 2004, 2008; Hanzelová et al., 2007; Ondračková et al., 2012; Sokolov et al., 2012a,b, 2013). Of the above specific parasite species of the Amur sleeper, Gyrodactylus perccotti, infecting 18\% of the fins in the studied Hungarian fish material, proved to be the most common in our studies. This monogenean was first isolated in the Carpathian basin by Ondračková et al. (2012). The monogenean Gyrodactylus spp., which has a direct development cycle and can infect fish for a long time, can easily be transmitted by the host. However, another monogenean, Ancyrocephalus curtus, which is common in China and the Far Eastern territories of Russia, has not been introduced to Europe.

Nippotaenia mogurndae was found to infect about $10 \%$ of the Amur sleepers examined in Hungary. It was common in some collecting places, achieving $60 \%$ infection rate, while in other collecting places it was not recorded at all. This parasite has been thoroughly studied in Slovakia (Košuthová et al., 2004, 2008, 2009; Hanzelová et al., 2007), Poland (Mierzejewska et al., 2010, 2012), Russia (Reshetnikov et al., 2011a,b) and the Ukraine (Kvach et al., 2013). The species develops via cyclops intermediate hosts, which makes possible its invasion also into Europe. It has been suggested that the infection of old specimens not feeding on plankton takes place by cannibalism (Reshetnikov et al., 2011a). Reshetnikov et al. (2011b) observed that the worms infect the host's gut only for a limited time. This means that the about $10 \%$ prevalence found in Hungarian fish specimens represents a relatively frequent infection.

The coccidian species Goussia obstinata with its $17 \%$ prevalence shows that it has found facilities for propagation in Hungary and, just like in Russia and Moldova (Sokolov and Moshu, 2013, 2014), causes frequent infection in Hungary as well. The species is long known from the original biotope but it was erroneously identified with $G$. carpelli and has only been recently described as $G$. obstinata (Sokolov and Moshu, 2014). Fish coccidia have a direct developmental cycle but tubificid carrier hosts promote their intensive invasion. They belong to species most commonly transmitted by invading species to the conquered new biotope, and have been described from several gobies in their new locations (Molnár, 2000, 2006). In this study they were found in both the Tisza and the Zala region.

With its $40 \%$ prevalence of infection, Trichodina mutabilis is the most common of the parasites known from Hungary, but the glochidial larvae of an Anodonta species also showed distinct signs on the fins and gills of Amur sleepers. The occurrence of encysted metacercariae of Opisthioglyphe ranae deserves mention because in Hungary these worms had never been diagnosed in fish before.

When considering the cause of colonisation of the hosts, a basic question was whether the dwarf goby and the Amur sleeper appeared in Europe as a result of the climate change or via introduction. Data suggest that the Amur sleeper had been introduced from the original biotope with unconsidered fish transfers 
(Reshetnikov, 2004), and it is one of the most invasive fish species in Eurasia in the past few decades (Copp et al., 2005; Reshetnikov and Ficetola, 2011; Reshetnikov, 2013). The short-lived Caucasian dwarf goby probably originates from the Black Sea, so it represents a unique type of spread of a goby species. It may have come to the Tisza River basin from Romania. The downstream spread of the species is extremely rapid, and its presence has been demonstrated also in Serbia (Harka et al., 2013, 2015a,b). From a parasitological point of view the important questions to be answered were how many parasites unknown in Hungarian fish basins had been carried to the new biotope and how these species could propagate there. It seems that the Amur sleeper transferred to Hungary only three specific parasites (Goussia obstinata, Gyrodactylus perccotti and Nippotaenia mogurndae) which do not endanger native fishes and do not cause intensive infection in the introduced hosts. Both fish species can be infected with the common wide host range parasites of Hungarian origin, of which Proteocephalus spp. deserve mention. While the Amur sleeper plays the same role for scolices of Proteocephalus percae as the common carrier host ruffe, the bleak parasite Proteocephalus sp. (presumably $P$. torulosus) can infect, and develop in, the dwarf goby but never achieves full maturity.

The low parasite infection level of these two invasive fish species may have contributed to their successful invasion into Hungary.

\section{Acknowledgements}

The authors express their thanks to colleagues for the collection of fish, especially to Péter Takács from the Balaton Limnological Institute of the Hungarian Academy of Sciences, and to Ákos Harka, Chairman of the Hungarian Ichthyological Society. Thanks are due to Tamás Arató from the National Food Chain Safety Office for his help with the transport of specimens. The project was supported by the Hungarian Scientific Research Fund (OTKA K100132) and by the Hungarian Government, managed by the National Development Agency, and financed by the KTIA_AIK_12-1-2013-0017-Bioclimate Program and SROP-4.2.2.B-15/1/KONV-2015-0001 projects. The project has been supported by the European Union and co-financed by the European Social Fund.

\section{References}

Bellard, C., Bertelsmeier, C., Leadley, P., Thuiller, W. and Courchamp, F. (2012): Impacts of climate change on the future of biodiversity. Ecol. Letters 15, 365-377.

Bíró, P. (1972): Neogobius fluviatilis in Lake Balaton - a Ponto-Caspian goby new to the fauna of Central Europe. J. Fish Biol. 4, 249-255.

Copp, G. H., Bianco, P. G., Bogutskaya, N. G., Erős, T., Falka, I., Ferreira, M. T., Fox, M. G., Freyhof, J., Gozlan, R. E., Grabowska, J., Kováč, V., Moreno-Amich, R., Naseka, A. M., Penáz, M., Povž, M., Przybylski, M., Robillard, M., Russell, I. C., Stakénas, S., Šumer, S., 
Vila-Gispert, A. and Wiesner, C. (2005): To be, or not to be, a non-native freshwater fish? J. Appl. Ichthyol. 21, 242-262.

Ergens, R., Gussev, A. V., Izyumova, N. A. and Molnár, K. (1975): Parasite fauna of fishes of the Tisa River basin. Rozpr. Česk. Akad. Věd Rada Mat. Přír. Věd 85, 1-117.

Erös, T. and Guti, G. (1997): The first record of Neogobius kessleri Günther, 1861 in the Hungarian section of the Danube [in Hungarian]. Halászat 90, 83-84.

Erős, T., Takács, P., Sály, P., Specziár, A., György, Á. I. and Bíró, P. (2008): Occurrence of Amur sleeper, Perccottus glenii Dybowski, 1877 in the water basin of Lake Balaton [in Hungarian]. Halászat 101, 75-77.

Francová, K., Ondračková, M., Polačik, M. and Jurajda, P. (2011): Parasite fauna of native and non-native populations of Neogobius melanostomus (Pallas, 1814) (Gobiidae) in the longitudinal profile of the Danube River. J. Appl. Ichthyol. 27, 879-886.

Guti, G. (2000): Dispersion of Ponto-Caspian gobiid fish (Gobiidae) in the middle Danubian basin [in Hungarian]. Hidrológiai Közlöny 80, 303-305.

Guti, G., Erős, T., Szalóky, Z. and Tóth, B. (2003): Round goby, Neogobius melanostomus (Pallas, 1811) in the Hungarian section of the Danube [in Hungarian]. Halászat 96, 116-119.

Halasi-Kovács, B., Antal, L. and Nagy, S. A. (2011): First record of a Ponto-Caspian Knipowitschia species (Gobiidae) in the Carpathian basin, Hungary. Cybium 35, 257-258.

Hanzelová, V., Dudinák, V. and Oros, M. (2007): Seasonality and maturation of alien invasive tapeworm Amurotaenia perccotti (Cestoda, Nippotaeniidea) in Slovakia. Parassitologia 49, 341.

Harka, Á. (1998): New fish species in the fauna of Hungary: Perccottus glehni Dybowski, 1877 [in Hungarian]. Halászat 91, 32-33.

Harka, Á. and Bíró, P. (2007): New patterns in Danubian distribution of Ponto-Caspian gobies - a result of global climatic change and/or canalization? Electron. J. Ichthyol. 3, 1-14.

Harka, Á., Halasi-Kovács, B., Sevcsik, A., Tóth, B. and Erős, T. (2005): The first data of racer goby [Neogobius gymnotrachelus (Kessler, 1857)] in the Hungarian stretch of River Danube [in Hungarian]. Halászat 98, 163-168.

Harka, Á., Šanda, R. and Halasi-Kovács, B. (2013): Appearance of a new invasive gobiid species in the Tisza river: the Caucasian dwarf goby - Knipowitschia caucasica (Berg, 1916), and first results of morphological and genetic study of the population [in Hungarian]. Pisces Hungarici 7, 5-11.

Harka, Á., Szepesi, Zs. and Sallai, Z. (2015a): Spreading of the tubenose goby (Proterorhinus semilunaris), the monkey goby (Neogobius fluviatilis) and the Caucasian dwarf goby (Knipowitschia caucasica) in the water system of the River Tisza [in Hungarian]. Pisces Hungarici 9, 19-30.

Harka, Á., Szepesi, Zs., Bajić, A. and Sipos, S. (2015b): First record of the invasive Caucasian dwarf goby - Knipowitschia caucasica (Berg, 1916) - in Serbia. Pisces Hungarici 9, 89-92.

Košuthová, L., Letková, V., Koščo, J. and Košuth, P. (2004): First record of Nippotaenia mogurndae Yamaguti and Miyata, 1940 (Cestoda: Nippotaeniidea), a parasite of Perccottus glenii Dybowski, 1877, from Europe. Helminthologia 41, 55-57.

Košuthová, L., Koščo, J., Letková, V., Košuth, P. and Manko, P. (2009): New records of endoparasitic helminths in alien invasive fishes from the Carpathian region. Biologia 64, 776-780.

Košuthová, L., Koščo, J., Miklisova, D., Letková, V., Košuth, P. and Manko, P. (2008): New data on an exotic Nippotaenia mogurndae (Cestoda), newly introduced to Europe. Helminthologia 45, 81-85.

Kvach, Y., Drobiniak, O., Kutsokon, Y. and Hoch, I. (2013): The parasites of the invasive Chinese sleeper Perccottus glenii (Fam. Odontobutidae), with the first report of Nippotaenia mogurndae in Ukraine. Knowl. Managt. Aquatic Ecosyst. 409, 05. DOI: http://dx.doi.org/ $10.1051 / \mathrm{kmae} / 2013048$.

Kvach, Y., Kornyychuk, Y., Mierzejewska, K., Rubtsova, N., Yurakhno, V., Grabowska, J. and Ovcharenko, M. (2014): Parasitization of invasive gobiids in the eastern part of the Central 
trans-European corridor of invasion of Ponto-Caspian hydrobionts. Parasitol. Res. 113, $1605-1624$

Mierzejewska, K., Kvach, Y., Woźniak, M., Kosowska, A. and Dziekońska-Rynko, J. (2012): Parasites of an Asian Fish, the Chinese sleeper Perccottus glenii, in the Wloclawek Reservoir on the Lower Vistula River, Poland: In search of the key species in the host expansion process. Comp. Parasitol. 79, 23-29.

Mierzejewska, K., Martyniak, A., Kakareko, T. and Hliva, P. (2010): First record of Nippotaenia mogurndae Yamaguti and Miyata, 1940 (Cestoda, Nippotaeniidae), a parasite introduced with Chinese sleeper to Poland. Parasitol. Res. 106, 451-456.

Miller, P. J. (2004): Knipowitschia Iljin, 1927. In: Miller, P. J. (ed.) The Freshwater Fishes of Europe, Volume 8, Gobiidae 2. AULA-Verlag, Wiesbaden, Germany. pp. 331-337.

Molnár, K. (1966): Untersuchungen über die jahreszeitlichen Schwankungen in der Parasitenfauna des Kaulbarsches und des Zanders in Balaton mit besonderer Berücksichtigung der Gattung Proteocephalus. Angew. Paras. 7, 65-77.

Molnár, K. (1979): Protozoan parasites of fish species indigenous in Hungary. Parasit. Hung. 12, $5-8$.

Molnár, K. (2000): Two new coccidia, a Goussia and an Eimeria spp. from the gut of Kessler's goby (Gobius kessleri Günther) in the River Danube. Acta Protozool. 39, 223-229.

Molnár, K. (2006): Some remarks on parasitic infections on the invasive Neogobius spp. (Pisces) in the Hungarian reaches of the Danube River, with description of Goussia szekelyi sp. n. (Apicomplexa: Eimeriidae). J. Appl. Ichthyol. 22, 395-400.

Ondračková, M., Matějusová, I. and Grabowska, J. (2012): Introduction of Gyrodactylus perccotti (Monogenea) into Europe on its invasive fish host, Amur sleeper (Perccottus glenii, Dybowski 1877). Helminthologia 49, 21-26.

Osmanov, S. O. (1971): Parasites of Uzbekistan's Fishes [in Russian]. FAN Publisher, Tashkent.

Prenter, J., MacNeil, C., Dick, J. T. A. and Dunn, A. M. (2004): Roles of parasites in animal invasions. Trends Ecol. Evol. 19, 385-390.

Rahel, F. J. and Olden, J. D. (2008): Assessing the effects of climate change on aquatic invasive species. Conserv. Biol. 22, 521-533.

Reshetnikov, A. N. (2004): The fish Perccottus glenii: history of introduction to western regions of Eurasia. Hydrobiologia 522, 349-350.

Reshetnikov, A. N. (2010): The current range of Amur sleeper Perccottus glenii Dybowski, 1877 (Odontobutidae, Pisces) in Eurasia. Russ. J. Biol. Invasions 1, 119-126.

Reshetnikov, A. N. (2013): Spatio-temporal dynamics of the expansion of rotan Perccottus glenii from West-Ukrainian centre of distribution and consequences for European freshwater ecosystems. Aquatic Invasions 8, 193-206.

Reshetnikov, A. N. and Ficetola, G. F. (2011): Potential range of the invasive fish Amur sleeper (Perccottus glenii) in the Holarctic. Biol. Invasions 13, 2967-2980.

Reshetnikov, A. N., Protasova, E. N., Sokolov, S. G., Pelgunov, A. N. and Voropaeva, E. L. (2011a): Infection of Perccottus glenii Dybowski, 1877 (Odontobutidae, Pisces) by parasite Nippotaenia mogurndae Yamaguti et Miyata, 1940 (Nippotaeniidae, Cestoda) through cannibalism [in Russian]. Russ. J. Biol. Invasions 2, 46-48.

Reshetnikov, A. N., Sokolov, S. G. and Protasova, E. N. (2011b): The host-specific parasite Nippotaenia mogurndae confirms introduction vectors of the fish Perccottus glenii in the Volga River basin. J. Appl. Ichthyol. 27, 1226-1231.

Sokolov, S. G. (2013): New data on the parasite fauna of the Chinese sleeper Perccottus glenii (Actinoperygii: Odontobutidae) in Primorsky Territory with the description of a new myxozoan species from the genus Myxidium (Myxozoa: Myxidiidae) [in Russian]. Parazitologiia 47, 77-99.

Sokolov, S. G. and Frolov, E. V. (2012): Diversity of parasites in the Amur sleeper (Perccottus glenii, Osteichthyes, Odontobutidae) within its native range [in Russian]. Zoologichesky Zhurnal 91, 17-29. 
Sokolov, S. G. and Moshu, A. Y. (2013): First data on parasites of Amur sleeper Perccottus glenii Dybowski, 1877 (Actinopterygii: Odintobutidae) in water bodies of the Republic of Moldova [in Russian]. Proceedings of the Samara Scientific Center of the Russian Academy of Sciences 15, 213-221.

Sokolov, S. G. and Moshu, A. Y. (2014): Goussia obstinata sp. n. (Sporozoa: Eimeriidae), a new coccidian species from intestines of the Amur sleeper Perccottus glenii Dybowski, 1877 (Perciformes: Odontobutidae) [in Russian]. Parazitologiia 48, 382-392.

Sokolov, S. G. and Zhukov, A. V. (2014): Variation trends in the parasite assemblages of the Chinese sleeper Perccottus glenii (Actinopterygii: Odontobutidae) in its native habitat [in Russian]. Biol. Bull. 41, 468-477.

Sokolov, S. G., Protasova, E. N. and Reshetnikov, A. N. (2013): Parasite fauna of rotan Perccottus glenii Dybowski, 1877 (Osteichthyes, Odontobutidae) in some water bodies of European Russia [in Russian]. Biology Bulletin 40, 862-871.

Sokolov, S. G., Protasova, E. N., Reshetnikov, A. N. and Schedko, M. B. (2012a): Parasites of introduced rotan Perccottus glenii (Actinopterygii: Odontobutidae) from water bodies of European Russia [in Russian]. Uspekhi Sovremennoi Biologii 132, 477-492.

Sokolov, S. G., Reshetnikov, A. N. and Protasova, E. N. (2014): A checklist of parasites in nonnative populations of rotan Perccottus glenii Dybowski, 1877 (Odontobutidae). J. Appl. Ichthyol. 30, 574-596.

Sokolov, S. G., Shedko, M. B., Protasova, E. N. and Reshetnikov, A. N. (2012b): The first record of Henneguya alexeevi (Myxozoa, Myxobolidae) in Europe [in Russian]. Vestnik Zoologii 46, 100-104.

Takács, P., Specziár, A., Erős, T., Sály, P. and Bíró, P. (2011): The composition of the fish fauna in the watershed of Lake Balaton [in Hungarian]. Ecology of Lake Balaton 1, 1-21.

Thomas, C. D., Cameron, A., Green, R. E., Bakkenes, M., Beaumont, L. J., Collingham, Y. C., Erasmus, B. F. N., de Siqueira, M. F., Grainger, A., Hannah, L., Hughes, L., Huntley, B., van Jaarsveld, A. S., Midgley, G. F., Miles, L., Ortega-Huerta, M. A., Peterson, A. T., Phillips, O. L. and Williams, S. E. (2004): Extinction risk from climate change. Nature 427, $145-148$.

Torchin, M. E., Lafferty, K. D., Dobson, A. P., McKenzie, V. J. and Kuris, A. M. (2003): Introduced species and their missing parasites. Nature 421, 628-630.

Vanhove, M. P. M., Economou, A. N., Zogaris, S., Giakoumi, S., Zanella, D., Volckaert, F. A. M. and Huyse, T. (2014): The Gyrodactylus (Monogenea, Gyrodactylidae) parasite fauna of freshwater sand gobies (Teleostei, Gobioidei) in their centre of endemism, with description of seven new species. Parasitol. Res. 113, 653-668.

Zaichenko, N. V. (2015): Parasite fauna of rotan Perccottus glenii Dybowski, 1877 (Osteichthyes: Odontobutidae) in some water bodies of Kiev region. Russian J. Biol. Invasions 6, 165-169. 